\title{
Hospital visitors as controls in case-control studies
}

\section{Visitantes hospitalares como controles em estudos caso-controle}

\author{
Gulnar Azevedo S Mendonça ${ }^{a}$ and José Eluf-Neto ${ }^{b}$ \\ alnstituto de Medicina Social da Universidade do Estado do Rio de Janeiro. Rio de Janeiro, RJ, Brasil. \\ ${ }^{b}$ Departamento de Medicina Preventiva da Faculdade de Medicina da Universidade de São Paulo. São \\ Paulo, SP, Brasil
}

\section{Keywords}

Case control studies." Breast neoplasms. Selection of controls. Hospital visitors controls.

\section{Descritores}

Estudos de casos e controles. ${ }^{\#}$ Neoplasmas mamários. Seleção de controles. Controles visitantes hospitalares.

\begin{abstract}
Objective

Selecting controls is one of the most difficult tasks in the design of case-control studies. Hospital controls may be inadequate and random controls drawn from the base population may be unavailable. The aim was to assess the use of hospital visitors as controls in a case-control study on the association of organochlorinated compounds and other risk factors for breast cancer conducted in the main hospital of the "Instituto Nacional de Câncer" - INCA (National Cancer Institute) in Rio de Janeiro (Brazil). Methods

The study included 177 incident cases and 377 controls recruited among female visitors. Three different models of control group composition were compared: Model 1, with all selected visitors; Model 2, excluding women visiting relatives with breast cancer; and Model 3, excluding all women visiting relatives with any type of cancer. Odds ratios (OR) and $95 \%$ confidence intervals were calculated to test the associations.

Results

Age-adjusted OR for breast cancer associated with risk factors other than family history of cancer, except smoking and breast size, were similar in the three models. Regarding family history of all cancers, except for breast cancer, there was a decreased risk in Models 1 and 2, while in Model 3 there was an increased risk, but not statistically significant. Family history of breast cancer was a risk factor in Models 2 and 3, but no association was found in Model 1. In multivariate analysis a significant risk of breast cancer was found when there was a family history of breast cancer in Models 2 and 3 but not in Model 1.

\section{Conclusions}

These results indicate that while investigating risk factors unrelated to family history of cancer, the use of hospital visitors as controls may be a valid and feasible alternative.
\end{abstract}

\section{Resumo}

\section{Objetivo}

A seleção de controles é uma das maiores dificuldades nos estudos caso-controle. Controles hospitalares podem ser inadequados, e controles selecionados aleatoriamente na população-base podem ser inacessíveis. Objetivou-se analisar

Supported by grant sponsor from Pan American Health Organization (reference: HDP/HDR/HCP/RG/BRA/1262). This study was carried out in "Instituto Nacional de Câncer", Rio de Janeiro, Brazil and in Departamento de Epidemiologia. Instituto de Medicina Social, Universidade do Estado do Rio de Janeiro. Presented in IV “Congresso Brasileiro de Epidemiologia", Rio de Janeiro, 1998.

Submitted on 5/9/2000. Reviewed on 21/3/2001. Approved on 1/8/2001

\section{Correspondence to:
Gulnar Azevedo S. Mendonça}

Depto Epidemiologia, Instituto de Medicina Social

Universidade do Estado do Rio de Janeiro

Rua São Francisco Xavier, 524, $7^{\circ}$ andar

20559-900, Rio de Janeiro, RJ, Brasil

E-mail: gulnar@uerj.br 
o uso de controles visitantes hospitalares em um estudo caso-controle conduzido no principal hospital do Instituto Nacional de Câncer, no Rio de Janeiro, RJ, que investigou a associação entre compostos organoclorados e outros fatores de risco para câncer de mama feminino.

\section{Métodos}

O estudo incluiu 177 casos incidentes e 377 controles recrutados entre visitantes mulheres. Três modelos de composição do grupo-controle foram comparados (modelo 1 , com todas as visitantes selecionadas; modelo 2, excluindo mulheres que visitavam parentes com câncer de mama; e modelo 3, excluindo todas as mulheres que visitavam parentes com qualquer tipo de câncer). Para testar as associações, foram calculados "odds ratios" e intervalos de confiança de $95 \%$.

\section{Resultados}

"Odds ratios" de câncer de mama ajustados por idade, associados a fatores de risco que não fossem a história familiar de câncer, com exceção de fumo e tamanho da mama, foram semelhantes nos três modelos. A história familiar de todos os cânceres, exceto mama, mostrou risco diminuído nos modelos 1 e 2, enquanto que no modelo 3, esteve associada ao aumento de risco, porém sem significado estatístico. A história familiar de câncer de mama foi um fator de risco para a doença nos modelos 2 e 3, mas não foi observada associação no modelo 1. Na análise multivariada, risco significante de câncer de mama foi encontrado para história familiar de câncer de mama nos modelos 2 e 3, mas não no modelo 1.

\section{Conclusões}

Os resultados indicam que, para investigar os fatores de risco não relacionados à história familiar de câncer, o uso de controles visitantes pode ser uma alternativa válida e viável.

\section{INTRODUCTION}

Selecting controls is one of the most difficult tasks in the design of case-control studies. The main purpose of control selection is to choose individuals representative of the base population. ${ }^{3,11,13}$ Estimates of risk in case-control studies will be unbiased if the probabilities of selection for both cases and controls do not vary between exposure groups. ${ }^{3}$ When controls are sampled from a primary base, it is easier to assess whether an individual is a member of the base. ${ }^{8,14}$ In many circumstances, however, it is almost impossible to include this type of control. Difficulties in obtaining a random sample of individuals from the general population, particularly in developing countries, limit the use of this type of control. Therefore, hospital controls have been widely used in casecontrol studies. As hospital controls are not healthy individuals, the exposure distribution to risk factors under study may be unrepresentative of the base-population. When cases are recruited from a cancer hospital, this may be a more important concern since controls are cancer patients.

In a case-control study on the association of organochlorinated compounds and other risk factors for female breast cancer, controls were selected among hospital visitors to that same hospital. ${ }^{7}$ Selection bias was assessed.

\section{METHODS}

\section{Study population}

Women admitted between May 1995 and July 1996 to the main hospital of the "Instituto Nacional de Câncer - INCA" (National Cancer Institute) in Rio de Janeiro with a clinical diagnosis of breast cancer in the previous six months were eligible for the study. Control subjects were recruited among visitors to the same hospital. Women who had ever had breast cancer were ineligible. Cases and controls had to be residents of the metropolitan region of Rio de Janeiro (Brazil) for at least six months. Women older than 75 years old or emotionally or clinically unfit to undergo an interview were excluded. There were approximately 2:1 controls per case, and they were frequency-matched to cases according to age groups (30-34, 35-39, 40-44, ..., 70-75).

A total of 221 cases were eligible before surgery. Two women refused to participate and 41 were diagnosed as benign breast disease. Three pathologists revised the histological slides of all eligible cases. One case was excluded due to an indeterminate diagnosis, leaving a total of 177 women with invasive breast cancer. Four hundred and seventytwo eligible visitor controls were identified, of whom 95 (20.1\%) refused to participate, alleging 
time constrains or emotional difficulties since they were visiting patients with advanced disease. Although it was not possible to properly characterize all refusals, it did not seem that these individuals were different from the studied individual regarding their age and the condition of being visiting relatives with cancer.

\section{Data and sample collection}

Data obtained using a standardized questionnaire included environmental and occupational exposure to pesticides, menstrual and reproductive history, family history of breast cancer and other cancers, smoking habits, alcohol drinking and breast size. Educational level was used as a surrogate of socioeconomic status. Since family history of cancer is a risk factor for the disease and could be more common among the control group, two questions were included in the questionnaire, one regarding the family kinship with the patient visited and the other about the patient's diagnosis. The method for determining DDE and other organochlorine levels in serum has been described elsewhere. ${ }^{7}$

The Research Committee of the Instituto Nacional de Câncer approved the study proposal and the procedure of informed consent obtained from all participating subjects.

\section{Analysis}

Three possible models of control group composition were considered in the analysis: Model $1(n=377)$ including all visitors selected; Model $2(n=350)$ excluding women visiting relatives with breast cancer; Model $3(n=214)$ excluding all women visiting relatives with any cancer.

Odds ratios (OR) and 95\% confidence intervals (CI) were calculated to estimate the risk of breast cancer associated with the studied factors using unconditional logistic regression. ${ }^{2}$

The association of p-p'-DDE and breast cancer was investigated by categorizing serum levels of this residue into quintiles based on the overall distribution of cases and controls. Other risk factors such as menarche age, menopausal status, parity, age at first and last full term pregnancy, months of lactation, tobacco smoking, alcohol drinking, body mass index, breast size and first-degree family history of breast cancer and other cancers were assessed. Alcohol consumption was quantified summing up doses of spirits, beer and wine. One cup of beer or wine was considered as one dose.
Statistical significance was assessed using the likelihood ratio test. ${ }^{2}$ For ordered variables, linear trend analyses were carried out by categorizing the exposure variables and treating the scores as continuous. Since cases and controls were frequency-matched according to age, all OR were adjusted to age (30-39, $40-44,45-49, \ldots, 70-75)$. Serum concentration of DDE, age, educational level, months of lactation, family history of breast cancer and variables in the 3 models with $\mathrm{p}<0.25$ after age-adjustment (parity, tobacco smoking, and breast size) were included in the final model. STATA software version 6.0 was used for statistical analysis.

\section{RESULTS}

A total of 177 cases and 377 controls were included

Table 1 - Odds ratios of breast cancer associated with selected variables - Model 1

\begin{tabular}{|c|c|c|c|c|}
\hline Variable* & Cases & Controls & $\mathrm{OR}^{* *}$ & $95 \% \mathrm{Cl}$ \\
\hline \multicolumn{5}{|l|}{ Educational level } \\
\hline Illiterate & 22 & 46 & 1.00 & \\
\hline Elementary school & 74 & 179 & 0.81 & $0.45-1.48$ \\
\hline Junior high school & 40 & 80 & 1.01 & $0.52-1.96$ \\
\hline Senior high school & 27 & 47 & 1.19 & $0.57-2.50$ \\
\hline College & 14 & 25 & 1.10 & $0.46-2.63$ \\
\hline$\chi^{2}$ for trend & & & $\mathrm{p}=0.34$ & \\
\hline \multicolumn{5}{|l|}{ Parity } \\
\hline None & 32 & 47 & 1.00 & \\
\hline $1-2$ & 64 & 147 & 0.61 & $0.35-1.05$ \\
\hline $3-4$ & 51 & 106 & 0.67 & $0.37-1.19$ \\
\hline$\geq 5$ & 30 & 77 & 0.52 & $0.27-1.00$ \\
\hline$\chi^{2}$ for trend & & & $p=0.12$ & \\
\hline \multicolumn{5}{|l|}{ Months of lactation } \\
\hline 0 & 42 & 75 & 1.00 & \\
\hline $1-3$ & 26 & 48 & 0.90 & $0.48-1.67$ \\
\hline 4-12 & 38 & 83 & 0.77 & $0.44-1.33$ \\
\hline $13-36$ & 32 & 84 & 0.62 & $0.35-1.10$ \\
\hline$>36$ & 39 & 87 & 0.77 & $0.44-1.34$ \\
\hline$\chi^{2}$ for trend & & & $p=0.19$ & \\
\hline \multicolumn{5}{|c|}{ Age at first full-term pregnancy*** (years) } \\
\hline 20 & 43 & 95 & 1.00 & \\
\hline $20-29$ & 79 & 199 & 0.88 & $0.56-1.39$ \\
\hline$\geq 30$ & 23 & 36 & 1.55 & $0.80-3.00$ \\
\hline$\chi^{2}$ for trend & & & $p=0.41$ & \\
\hline \multicolumn{5}{|l|}{ Breast size } \\
\hline Small & 53 & 103 & 1.00 & \\
\hline Median & 40 & 116 & 0.75 & $0.45-1.24$ \\
\hline Large & 38 & 85 & 0.95 & $0.56-1.61$ \\
\hline Very large & 45 & 73 & 1.31 & $0.77-2.22$ \\
\hline$\chi^{2}$ for trend & & & $p=0.25$ & \\
\hline \multicolumn{5}{|c|}{ Tobacco smoking (pack-years) } \\
\hline Never smoked & 113 & 251 & 1.00 & \\
\hline$<20$ & 35 & 91 & 0.86 & $0.54-1.36$ \\
\hline $20-39$ & 20 & 24 & 1.80 & $0.94-3.44$ \\
\hline$\geq 40$ & 9 & 10 & 1.94 & $0.75-5.02$ \\
\hline$\chi^{2}$ for trend & & & $p=0.10$ & \\
\hline \multicolumn{5}{|c|}{ Alcohol drinking (dose-years) } \\
\hline Never drank & 103 & 219 & 1.00 & \\
\hline $0.01-0.49$ & 10 & 24 & 0.91 & $0.41-2.02$ \\
\hline $0.50-1.99$ & 18 & 54 & 0.70 & $0.39-1.28$ \\
\hline $2.00-9.99$ & 16 & 43 & 0.78 & $0.42-1.47$ \\
\hline$\geq 10$ & 29 & 30 & 2.11 & $1.19-3.75$ \\
\hline$\chi^{2}$ for trend & & & $p=0.21$ & \\
\hline \multicolumn{5}{|c|}{ Serum level of DDE (ng/mL) } \\
\hline$<1.3$ & 29 & 71 & 1.00 & \\
\hline $1.3-2.4$ & 32 & 71 & 1.03 & $0.55-1.89$ \\
\hline $2.5-3.9$ & 35 & 63 & 1.45 & $0.78-2.70$ \\
\hline $4.0-7.6$ & 37 & 79 & 1.06 & 0.57-1.95 \\
\hline$>7.6$ & 29 & 74 & 0.93 & $0.49-1.78$ \\
\hline$\chi^{2}$ for trend & & & $p=0.78$ & \\
\hline
\end{tabular}

*Total may vary because of missing data.

**Age-adjusted.

***Among parous women. 
in the study. In the control group, 163 women were visiting relatives with any type of cancer and 27 were visiting relatives with breast cancer.

Age-adjusted OR of breast cancer associated with risk factors other than family history of cancer, except for smoking, were similar in all three models (Tables 1-3). In Model 3, the risks related to higher tobacco consumption (20-39 and ${ }^{3} 40$ pack-years) increased

Table 2 - Odds ratio of breast cancer associated with selected factors - Model 2.

\begin{tabular}{|c|c|c|c|c|}
\hline Variable* & Cases & Controls & $\mathrm{OR}^{* *}$ & $95 \% \mathrm{Cl}$ \\
\hline \multicolumn{5}{|l|}{ Educational level } \\
\hline Illiterate & 22 & 40 & 1.00 & \\
\hline Elementary school & 74 & 168 & 0.76 & $0.42-1.39$ \\
\hline Junior high school & 40 & 74 & 0.96 & $0.49-1.89$ \\
\hline Senior high school & 27 & 44 & 1.10 & $0.52-2.34$ \\
\hline College & 14 & 24 & 1.01 & $0.42-2.43$ \\
\hline$\chi^{2}$ for trend & & & $\mathrm{p}=0.42$ & \\
\hline Parity & & & & \\
\hline None & 32 & 43 & 1.00 & \\
\hline $1-2$ & 64 & 139 & 0.59 & $0.34-1.03$ \\
\hline $3-4$ & 51 & 100 & 0.66 & $0.37-1.19$ \\
\hline$\geq 5$ & 30 & 68 & 0.54 & $0.28-1.04$ \\
\hline $\bar{\chi}^{2}$ for trend & & & $p=0.16$ & \\
\hline Months of lactation & & & & \\
\hline 0 & 42 & 70 & 1.00 & \\
\hline $1-3$ & 26 & 46 & 0.88 & $0.47-1.64$ \\
\hline $4-12$ & 38 & 80 & 0.75 & $0.43-1.30$ \\
\hline $13-36$ & 32 & 76 & 0.65 & $0.36-1.16$ \\
\hline$>36$ & 39 & 78 & 0.81 & $0.46-1.42$ \\
\hline$\chi^{2}$ for trend & & & $\mathrm{p}=0.29$ & \\
\hline \multicolumn{5}{|c|}{ Age at first full-term pregnancy*** (years) } \\
\hline 20 & 43 & 85 & 1.00 & \\
\hline $20-29$ & 79 & 187 & 0.84 & $0.53-1.33$ \\
\hline$\geq 30$ & 23 & 35 & 1.44 & $0.74-2.82$ \\
\hline $\bar{\chi}^{2}$ for trend & & & $\mathrm{p}=0.55$ & \\
\hline Breast size & & & & \\
\hline Small & 53 & 97 & 1.00 & \\
\hline Median & 40 & 109 & 0.76 & $0.46-1.28$ \\
\hline Large & 38 & 78 & 1.00 & $0.58-1.70$ \\
\hline Very large & 45 & 66 & 1.38 & $0.80-2.37$ \\
\hline$\chi^{2}$ for trend & & & $p=0.17$ & \\
\hline \multicolumn{5}{|c|}{ Tobacco smoking (pack-years) } \\
\hline Never smoked & 113 & 234 & 1.00 & \\
\hline$<20$ & 35 & 82 & 0.89 & $0.56-1.43$ \\
\hline $20-39$ & 20 & 23 & 1.74 & $0.90-3.35$ \\
\hline$\geq 40$ & 9 & 10 & 1.81 & $0.70-4.70$ \\
\hline$\chi^{2}$ for trend & & & $\mathrm{p}=0.12$ & \\
\hline \multicolumn{5}{|c|}{ Alcohol drinking (dose-years) } \\
\hline Never drank & 103 & 201 & 1.00 & \\
\hline $0.01-0.49$ & 10 & 20 & 0.97 & $0.43-2.20$ \\
\hline $0.50-1.99$ & 18 & 52 & 0.68 & $0.37-1.24$ \\
\hline $2.00-9.99$ & 16 & 42 & 0.74 & $0.40-1.41$ \\
\hline$\geq 10$ & 29 & 28 & 2.10 & $1.17-3.76$ \\
\hline$\chi^{2}$ for trend & & & $p=0.28$ & \\
\hline \multicolumn{5}{|c|}{ Serum level of DDE (ng/mL) } \\
\hline$<1.3$ & 29 & 66 & 1.00 & \\
\hline $1.3-2.4$ & 32 & 65 & 1.03 & 0.55-1.92 \\
\hline $2.5-3.9$ & 35 & 58 & 1.45 & $0.76-2.71$ \\
\hline $4.0-7.6$ & 37 & 73 & 1.06 & $0.56-1.97$ \\
\hline$>7.6$ & 29 & 69 & 0.90 & $0.47-1.74$ \\
\hline$\chi^{2}$ for trend & & & $p=0.78$ & \\
\hline
\end{tabular}

*Total may vary because of missing data

**Age-adjusted.

***Among parous women. and it was observed a statistically significant trend.

Regarding family history of cancer, there was seen great variation between the three models (Table 4). Considering all cancers except breast cancer, family history showed a decreased risk for the disease in Models 1 and 2, while it was associated with an increased risk in Model 3 (although not statistically significant). Family history of breast cancer was a risk

Table 3 - Odds ratios of breast cancer associated with selected variables - Model 3.

\begin{tabular}{|c|c|c|c|c|}
\hline Variable* & Cases & Controls & $\mathrm{OR}^{* *}$ & $95 \% \mathrm{Cl}$ \\
\hline \multicolumn{5}{|l|}{ Educational level } \\
\hline Illiterate & 22 & 26 & 1.00 & \\
\hline Elementary school & 74 & 103 & 0.75 & $0.39-1.47$ \\
\hline Junior high school & 40 & 44 & 0.96 & $0.43-2.28$ \\
\hline Senior high school & 27 & 28 & 0.99 & $0.36-2.68$ \\
\hline College & 14 & 13 & 0.99 & $0.36-2.68$ \\
\hline$\chi^{2}$ for trend & & & $p=0.59$ & \\
\hline Parity & & & & \\
\hline None & 32 & 25 & 1.00 & \\
\hline $1-2$ & 64 & 185 & 0.58 & $0.30-1.10$ \\
\hline $3-4$ & 51 & 62 & 0.68 & $0.35-1.32$ \\
\hline$\geq 5$ & 30 & 42 & 0.53 & $0.25-1.09$ \\
\hline $\bar{\chi}^{2}$ for trend & & & $\mathrm{p}=0.20$ & \\
\hline Months of lactation & & & & \\
\hline 0 & 42 & 37 & 1.00 & \\
\hline $1-3$ & 26 & 30 & 0.70 & $0.34-1.44$ \\
\hline $4-12$ & 38 & 50 & 0.61 & $0.32-1.15$ \\
\hline $13-36$ & 32 & 51 & 0.55 & $0.29-1.05$ \\
\hline$>36$ & 39 & 46 & 0.74 & $0.39-1.41$ \\
\hline$\chi^{2}$ for trend & & & $\mathrm{p}=0.25$ & \\
\hline \multicolumn{5}{|c|}{ Age at first full-term pregnancy*** (years) } \\
\hline 20 & 43 & 49 & 1.00 & \\
\hline $20-29$ & 79 & 117 & 0.72 & $0.42-1.21$ \\
\hline$\geq 30$ & 23 & 23 & 1.22 & $0.58-2.59$ \\
\hline $\bar{\chi}^{2}$ for trend & & & $p=0.96$ & \\
\hline Breast size & & & & \\
\hline Small & 53 & 59 & 1.00 & \\
\hline Median & 40 & 68 & 0.82 & $0.46-1.45$ \\
\hline Large & 38 & 45 & 1.28 & $0.69-1.70$ \\
\hline Very large & 45 & 42 & 1.55 & $0.88-2.89$ \\
\hline$\chi^{2}$ for trend & & & $p=0.07$ & \\
\hline \multicolumn{5}{|c|}{ Tobacco smoking (pack-years) } \\
\hline Never smoked & 113 & 149 & 1.00 & \\
\hline$<20$ & 35 & 50 & 0.94 & $0.56-1.59$ \\
\hline $20-39$ & 20 & 9 & 2.72 & $1.16-6.37$ \\
\hline$\geq 40$ & 9 & 5 & 2.73 & $0.85-8.72$ \\
\hline$\chi^{2}$ for trend & & & $p=0.02$ & \\
\hline \multicolumn{5}{|c|}{ Alcohol drinking (dose-years) } \\
\hline Never drank & 103 & 125 & 1.00 & \\
\hline $0.01-0.49$ & 10 & 11 & 1.21 & $0.47-3.11$ \\
\hline $0.50-1.99$ & 18 & 33 & 0.72 & $0.37-1.40$ \\
\hline $2.00-9.99$ & 16 & 29 & $0.6 \overline{6}$ & $0.33-1.30$ \\
\hline$\geq 10$ & 29 & 13 & 2.75 & $1.33-5.71$ \\
\hline$\chi^{2}$ for trend & & & $p=0.26$ & \\
\hline \multicolumn{5}{|c|}{ Serum level of DDE (ng/mL) } \\
\hline$<1.3$ & 29 & 41 & 1.00 & \\
\hline $1.3-2.4$ & 32 & 38 & 1.11 & $0.55-2.23$ \\
\hline $2.5-3.9$ & 35 & 35 & 1.56 & $0.77-3.16$ \\
\hline $4.0-7.6$ & 37 & 40 & 1.14 & $0.56-2.30$ \\
\hline$>7.6$ & 29 & 46 & 0.93 & $0.45-1.92$ \\
\hline$\chi^{2}$ for trend & & & $p=0.84$ & \\
\hline
\end{tabular}

*Total may vary because of missing data.

**Age-adjusted.

***Among parous women.

Table 4 - Odds ratio* of breast cancer associated with family history of cancer.

\begin{tabular}{|c|c|c|c|c|c|c|c|}
\hline \multirow{2}{*}{$\begin{array}{l}\text { Family history } \\
\text { of cancer** }\end{array}$} & \multirow[b]{2}{*}{$\mathrm{N}$ cases } & \multicolumn{2}{|c|}{ Model 1} & \multicolumn{2}{|c|}{ Model 2} & \multicolumn{2}{|c|}{ Model 3} \\
\hline & & $\mathrm{N}$ cont. & OR $(95 \% \mathrm{Cl})$ & $\mathrm{N}$ cont. & OR $(95 \% \mathrm{Cl})$ & $\mathrm{N}$ cont. & OR $(95 \% \mathrm{Cl})$ \\
\hline All types excep & & & & & & & \\
\hline $\begin{array}{l}\text { No } \\
\text { Yes }\end{array}$ & 113 & 212 & 1.00 & 198 & 1.00 & 152 & 1.00 \\
\hline $\begin{array}{l}\text { Yes } \\
\text { Breast cancer }\end{array}$ & 57 & 164 & $0.66(0.45-0.97)$ & 151 & $0.66(0.44-0.97)$ & 61 & $1.39(0.88-2.20)$ \\
\hline No & 153 & 339 & 1.00 & 336 & 1.00 & 204 & 1.00 \\
\hline Yes & 17 & 37 & $1,02(0.55-1.90)$ & 13 & $3.15(1.46-6.77)$ & 9 & $2.84(1.20-6.73)$ \\
\hline
\end{tabular}

*Age-adjusted

**Missing values for 7 cases and 1 control. 
factor for the disease in Models 2 and 3, but there was no association in Model 1.

The multivariate analysis results did not differ substantially in the three models, except for family history of breast cancer, smoking and breast size (Table 5). A significant risk of breast cancer was found regarding family history of breast cancer in Models 2 and 3 (not in Model 1). For tobacco smoking, higher odds ratios in high consumption categories were seen in Model 3 (although not statistically significant). On the other hand, a statistically significant association was found for breast size in Model 3 ( $p$ for linear trend $=0.03$ ).

The analysis taking into account the main risk factors under study was repeated comparing only two of the control groups: a) women visiting patients with any type of cancer, and b) women visiting patients who are not their relatives. In this analysis, it was found that the results including family history of cancer (breast cancer or all types except breast cancer), serum level of DDE and smoking, were compatible with the previous ones (data not shown).

\section{DISCUSSION}

In this study, the values of age-adjusted and multivariate odds ratios of breast cancer associated with risk factors, other than family history of cancer, tobacco smoking, and breast size, revealed little vari- ation in the three models of control group composition. In fact, it was expected that the odds ratios would be close in Models 1 and 2, since Model 2 included more than $90 \%$ of the individuals included in Model 1 . The observed odds ratios of breast cancer associated with classic risk factors as parity, lactation and age at first full term pregnancy did not show statistically significant differences in the three models, although the risk directions were as expected which could be explained by the small sample size of studied population.

Differences in odds ratios were seen regarding family history of cancer. For any cancer other than breast, when the control group included all visitors recruited (women visiting relatives and women visiting nonrelatives with cancer - Model 1), or when only the 27 women visiting relatives with breast cancer were excluded (Model 2), a decreased risk was observed. Excluding all visitors of relatives with cancer (Model 3), an increased risk was found, although not statistically significant. These findings indicate the existence of selection bias related to family history of cancer. Considering family history of breast cancer, selection bias due to the inclusion of 27 women visiting relatives with breast cancer masked the effect in Model 1.

A statistically significant trend of increasing risk (age-adjusted) of breast cancer with history of increas-

Table 5 - Odds ratios* for breast cancer according to selected variables.

\begin{tabular}{|c|c|c|c|}
\hline Variable & $\begin{array}{c}\text { Model } 1 \\
\text { OR }(95 \% \mathrm{Cl})\end{array}$ & $\begin{array}{c}\text { Model } 2 \\
\text { OR }(95 \% \mathrm{Cl})\end{array}$ & $\begin{array}{c}\text { Model } 3 \\
\text { OR }(95 \% \mathrm{Cl})\end{array}$ \\
\hline \multicolumn{4}{|c|}{ Serum level of $p-p^{\prime}$ DDE (ng/mL) } \\
\hline$<1.3$ & 1.00 & 1.00 & 1.00 \\
\hline $1.3-2.4$ & $0.87(0.46-1.69)$ & $0.95(049-1.85)$ & $1.09(0.51-2.33)$ \\
\hline $2.5-3.9$ & $1.38(0.72-2.66)$ & $1.34(0.68-2.64)$ & $1.51(0.69-3.28)$ \\
\hline $4.0-7.6$ & $1.08(0.57-2.04)$ & $1.12(0.58-2.15)$ & $1.08(0.51-2.29)$ \\
\hline$>7.6$ & $0.82(0.41-1.62)$ & $0.83(0.41-1.66)$ & $0.72(0.33-1.60)$ \\
\hline$\chi^{2}$ for trend & $\mathrm{p}=0.81$ & $p=0.79$ & $\mathrm{P}=0.47$ \\
\hline \multicolumn{4}{|l|}{ Parity } \\
\hline None & 1.00 & 1.00 & 1.00 \\
\hline $1-2$ & $0.53(0.20-1.38)$ & $0.50(0.19-1.35)$ & $0.79(0.25-2.52)$ \\
\hline $3-4$ & $0.71(0.25-1.96)$ & $0.67(0.24-1.88)$ & $1.10(0.32-3.75)$ \\
\hline$\geq 5$ & $0.43(0.14-1.33)$ & $0.43(0.14-1.36)$ & $0.66(0.18-2.45)$ \\
\hline $\bar{\chi}^{2}$ for trend & $p=0.47$ & $\mathrm{p}=0.50$ & $\mathrm{p}=0.80$ \\
\hline \multicolumn{4}{|c|}{ Months of lactation } \\
\hline 0 & 1.00 & 1.00 & 1.00 \\
\hline $1-3$ & $1.40(0.53-3.68)$ & $1.31(0.49-3.51)$ & $0.74(0.23-2.32)$ \\
\hline $4-12$ & $1.25(0.50-3.13)$ & $1.24(0.49-3.17)$ & $0.75(0.25-2.24)$ \\
\hline $3-36$ & $0.94(0.36-2.45)$ & $1.01(0.38-2.70)$ & $0.56(0.18-1.73)$ \\
\hline$>36$ & $1.08(0.41-2.88)$ & $1.20(0.44-3.23)$ & $0.75(0.24-2.35)$ \\
\hline$\chi^{2}$ for trend & $p=0.65$ & $p=0.96$ & $\mathrm{p}=0.63$ \\
\hline \multicolumn{4}{|c|}{ Tobacco smoking (pack-years) } \\
\hline Never & 1.00 & 1.00 & 1.00 \\
\hline$<20$ & $0.76(0.46-1.27)$ & $0.73(0.43-1.23)$ & $0.75(0.41-1.36)$ \\
\hline $20-39$ & $1.60(0.77-3.30)$ & $1.52(0.72-3.18)$ & $3.02(1.12-8.10)$ \\
\hline$\geq 40$ & $1.18(0.33-4.21)$ & $1.07(0.29-3.93)$ & $2.60(0.54-12.54)$ \\
\hline $\bar{\chi}^{2}$ for trend & $p=0.60$ & $p=0.77$ & $\mathrm{p}=0.11$ \\
\hline \multicolumn{4}{|c|}{ Family history of breast cancer } \\
\hline Nó & 1.00 & 1.00 & 1.00 \\
\hline Yes & $1.03(0.53-2.01)$ & $3.20(1.37-7.46)$ & $3.10(1.14-8.45)$ \\
\hline \multicolumn{4}{|l|}{ Breast size } \\
\hline Small & 1.00 & 1.00 & 1.00 \\
\hline Median & $0.65(0.37-1.15)$ & $0.68(0.38-1.20)$ & $0.68(0.35-1.29)$ \\
\hline Large & $1.00(0.56-1.80)$ & $1.02(0.56-1.84)$ & $1.51(0.76-2.99)$ \\
\hline Very large & $1.44(0.79-2.63)$ & $1.47(0.79-2.71)$ & $1.77(0.87-3.61)$ \\
\hline$\chi^{2}$ for trend & $p=0.14$ & $p=0.14$ & $p=0.03$ \\
\hline
\end{tabular}

*Adjusted by age, educational level and the other variables in the table. 
ing tobacco smoking was observed only in Model 3. This finding, however, proved to be not significant after controlling for other variables. Smoking habits are frequently seen in the same family, which could explain the increased risk when women visiting relatives with cancer were excluded from the control group.

The lack of other types of controls in this study limits the possibilities of better exploring the occurrence of selection bias. Nevertheless, hospital visitor controls have been shown to be comparable to other types of controls in many aspects. ${ }^{1,9}$ Recent case-control studies of cancer have used hospital visitors as controls, ${ }^{4,5,15}$ but there was no discussion about their limitations and advantages. MacMahon \& Trichopoulos 6 pointed out to the fact that few studies report the convenience of using hospital visitors as controls. Armenian et $\mathrm{al}^{1}$ find this type of controls more adequate in favor of a pragmatic and methodological sense.

The selection of a appropriate control group, namely hospital or population controls, has been a controversial issue among epidemiologists. ${ }^{8,12,14}$ Casecontrol studies of cancer are frequently conducted in cancer hospitals, since many individuals with the disease are referred to and treated in specialized hospitals. It is known that hospital control patients may have a different exposure distribution compared to the base-population. ${ }^{10}$ Since visitor controls are theoretically not ill, this problem should be seen less often. It should also be taken into account that hospital visitors tend to derive from the same hypothetical population where cases were originated, these individuals having the same chance of being included as cases if they were to develop cancer under study. ${ }^{2}$

In case-control studies, the number of available con- trols has practical implications. On this aspect, Model 2 , which included more than $90 \%$ of Model 1's individuals, was better than Model 3, which included less than $60 \%$.

Controls recruited in hospital, either as patients or visitors, show some advantages. Apart from the fact that they are sometimes more representative of the base population than community controls, they are usually more collaborative. When there is a need of collecting biological specimens, which is increasingly the case in epidemiological studies, this can be a very important advantage. It is well recognized that no one type of control group can be suitable for all studies, and as there are no definite criteria of what an acceptable group is ${ }^{2}$ this specific situation might be regarded as a practical advantage of using visitors controls.

The study findings indicate that hospital visitor controls can create selection bias regarding family history of cancer. However, the majority of risk factors investigated were not confounded by family history of cancer, such as serum concentration of DDE. The exclusion of women visiting relatives with breast cancer, though slightly reduced the number of eligible controls, seemed to have prevented selection bias. This option offered a feasible alternative, indicating that the use of hospital visitors as controls should be explored in further case-control studies.

\section{ACKNOWLEDGMENTS}

To A. L. Eisemberg, MD and L. M. Magalhães, MD for the histopathological review of all cases and to the medical and nursing staff of the mastology division and outpatient clinics of "Hospital do Câncer/ Instituto Nacional de Câncer" for their collaboration.

\section{REFERENCES}

1. Armenian HK, Larkis NG, Sirai AM, Halabi SS. Hospital visitors as controls. Am J Epidemiol 1988;127:404-6.

2. Breslow NE, Day NE, editors. Statistical methods in cancer research. Lyon: International Agency for Research on Cancer; 1980. v. 1. The analysis of casecontrol studies.

3. Clayton D, Hills M. Statistical models in epidemiology. Oxford: Oxford Science Publications; 1993. p. 153-65. Chap 16: Case-control studies.

4. Kalapothaki V, Tzonou A, Hsieh CC, Karakatsani A, Trichopoulou A, Toupadaki $\mathrm{N}$ et al. Nutrient intake and cancer of the pancreas: a case-control study in Athens, Greece. Cancer Causes Control 1993;4:383-9.
5. Katsouyanni K, Lipworth L, Trichopoulou A, Samoli E, Stuver S, Trichopoulos D. A case-control study of lactation and cancer or the breast. $\mathrm{Br} / \mathrm{Cancer}$ 1996;73:814-8.

6. MacMahon B, Trichopoulos D. Epidemiology: principles and methods - Sources and methods for control selection. Boston: Little, Brown and Company; 1996. p.253-64.

7. Mendonça GAS, Eluf-Neto J, Andrada-Serpa MJ, Carmo $\mathrm{PA}$, Barreto $\mathrm{HH}$, Inomata ON et al. Organochlorines and breast cancer: a case-control study in Brazil. Int J Cancer 1999;83:596-600. 
8. Miettinem OS. The case-control study: valid selection of subjects. J Chronic Dis 1985;38:543-8.

9. Ngelangel CA. Hospital visitor-companions as a source of controls for case-control studies in the Philippines. Int J Epidemiol 1989;18(4 Suppl 2):S50-S3.

10. Oslon SH, Kelsey JL, Pearson TA, Levin B.

Characteristics of a hypothetical group of hospital controls for a case-control study. Am J Epidemiol 1994;139:302-11.

11. Rothman KJ, Greenland S. Case-control studies. In: Rothman KJ, Greenland S. Modern epidemiology, New York: Lippincott-Raven; 1998. p.93-114.
12. Spitzer WO. Ideas and words: two dimensions for debates on case controlling. J Chron Dis 1985;38:541-2.

13. Wacholder S, McLaughlin JK, Silverman DT, Mandel JS. Selection of controls in case-control studies. I. Principles. Am J Epidemiol 1992;135:1019-28.

14. Wacholder S, Silverman DT, McLaughlin JK Mandel JS. Selection of controls in case-control studies. II. Types of controls. Am / Epidemiol 1992;135:1029-41.

15. Zaridze D, Evstifeeva T, Babaeva M, Boyle P. Fats used in seasoning and breast cancer risk: a case-control study in Moscow, Russia. Ann Oncol 1993;4:495-8. 